\title{
Almond: A Diverse Germplasm
}

Almond [Prunus amygdalus Batsch syn. P. dulcis (Mill.) D.A. Webb] is a stone fruit grown for its kernels (seeds) in several countries with Mediterranean-type climates (Kester and Asay, 1975). It has been grown for many centuries, domesticated perhaps during the third millennium BC (Spiegel-Roy, 1986). Almond cultivation has expanded from Central Asia, where it originated (Kovalyov and Kostina, 1935), toward and around the Mediterranean Sea, and then to both North and South America, South Africa, and Australia.

Wild almond trees are still found in Central Asia (Popov et al., 1929). Many wild species that are related to almond and that intercross freely with it also have been described for this region (Grasselly, 1976). Among these species, probably $P$. fenzliana Fritsch., $P$. bucharica (Korsh.) Fedtsch., P. kuramica (A. kuramica Korsh.), and P. triloba Lindl. have been involved in various hybridizations, giving rise to the current almond cultivars (Grasselly and Crossa-Raynaud, 1980; Kester et al., 1990). Furthermore, as the almond moved toward the Mediterranean, new hybridizations might have occurred, especially with the wild Mediterranean species, P. webbii (Spach) Vierh. (Godini, 1979; Sociasi Company, 1990), resulting in some of the almond populations found along the northern border of the Mediterranean Sea, from Greece and the Balkans to Spain and Portugal.

Presumably, almond was introduced to the Mediterranean area through seeds carried by caravans crossing the Central Asian steppes on their way from China to the West. Almond cultivation had to exist in Greece long before the creation of the Greek myths to explain its incorporation into them (Graves, 1955); also, there is evidence for an almond trade in the fourth century BC (Cerdá Juan, 1973). The Mediterranean's favorable climate and the almond's hardiness (as related to water and soil requirements), good quality, and nutritious value allowed cultivation to expand along the Mediterranean coast. Almond cultivation and trade were already established along the western shore of the Mediterranean, in Spain, during the first century of this era (Colls et al., 1985). Later, the migration from the Old World to the newly explored continents continued the expansion of this crop to regions where the climate was also favorable for its growth. This movement was mainly by seeds, leading to new cultivars and forms in the New World.

Received for publication 17 Dec. 1991. Accepted forpublication 18 Mar. 1991. The cost of publishing this paper was defrayed in part by the payment of page charges. Under postal regulations, this paper therefore must be hereby marked advertisement solely to indicate this fact.

Front Cover: Different forms and sizes of almond fruits (photograph by A.J. Felipe).
Spain traditionally has been the second most important almond producer in the world. In 1966, when research on almond was launched in our department, the biggest producer was Italy, and the third, the United States; but now these two countries have exchanged places, with Spain maintaining second place.

The first step in our department was the formation of a collection of the most important commercial cultivars of Spanish and foreign origin. Gradually, local selections also were added when they revealed relevant traits. This collection demonstrates that almond is a very heterogeneous species. This heterogeneity is probably a consequence of the almond's ancient origin, its traditional culture in many diverse areas, with local adaptations to different microclimates, and its being an obligate outcrosser due to self-incompatibility (Socias i Company, 1977), a trait that probably resulted due to its particular evolution (Watkins, 1979). Our collection has been the base of several studies, such as blooming aspects, cross-pollination assays, cultivar descriptions, etc. (Felipe and Socias i Company, 1985a).

Our collection represents cultivars from all the almond-growing areas of the world and serves as reference for the Group de Recherches et d'Etudes Méditerranéen pour l'Amandier (GREMPA) (Mediterranean Group for Almond Research and Study), which was founded in 1974 in Zaragoza and includes members from 14 countries. This group has held eight meetings, the last one in June 1990 in Nimes, France, to encourage the exchange of knowledge and plant material among all researchers. Ours is also the almond base collection of the Spanish Fruit Germplasm Network.

Observations of this collection have allowed us to conclude:

1) There is wide variability for many traits within the species. The differences observed are much wider than in other closely related species, e.g., peach $[P$. persica (L.) Batsch]. This variability is especially relevant for blooming date due to the coincidence of early blooming in almond and the prevalence of spring frosts. More than 1 month elapses between the beginning of the bloom periods of the early and late-blooming cultivars; thus, the flowering season may last longer than 2 months. Noticeable differences have also been observed in other traits, such as growth habit, bearing type, etc., among different cultivars.

2) Self-compatible cultivars, a very important trait in almond (Socias i Company, 1990), do exist (Herrero and Felipe, 1975). This observation has been the starting point for an almond breeding program in Spain (Felipe and Socias i Company, 1985b), which has already resulted in three new cultivars: 'Aylés', 'Guara', and 'Moncayo' (Felipe and Socias i Company, 1987).

3) This species, thus far given only limited study, still offers wide possibilities for improvement, both in productivity and fruit quality.

Along with the cultivar collection, GREMPA maintains a collection of wild species closely related to almond. Zaragoza was again selected as the site for this collection because of its dry and continental climate, resembling that of the original sites of many of these species (Felipe, 1984).

This collection of wild species was initiated by an expedition to Afghanistan in June 1975 by Charles Grasselly (INRA, France) and A.J.F. with the support of local government officers. In Afghanistan, as in surrounding countries, many wild relatives of almond have been located, studied, and described by several botanists (Grasselly, 1976). Seeds and graftwood from six species were collected, serving as a nucleus for this collection. Other seeds were obtained from Iran and from the republics of Central Asia through the Nikitskij Botanical Garden of Yalta(Crimea). The Mediterranean species $P$. webbii was introduced through seeds from Sicily and Crete, and also through seeds of a Spanish population that appears to belong to the same species, although with some variation probably due to its isolation and ease and frequency of hybridization with the cultivated almond (Socias i Company and Felipe, 1988).

The species represented in this collection are: $P$. fenzliana Fritsch., P. bucharica (Korsh.) Fetdsch., $P$. spinosissima (Bge.) Franch., $P$. webbii, $P$. triloba Lindl.. P. zabulica Seraf., $P$. kuramica (A. kuramica Korsh.), P. brahuica Aitch. et Hemsl., and P. kotschii (A. kotschii Boiss.). Seeds have been collected from most of them, with the exception of $P$. zabulica. Studies on vegetative propagation and selfcompatibility have been carried out in most of these species.

Both the cultivar collection and the wild species show how almond as a species and as a botanical group of species intercrosses easily, thus opening the possibility of modifying and improving the diverse and useful traits for new almond cultivars.

\section{Literature Cited}

Cerdá Juan, D. 1973. Economía antigua de Mallorca, p. 417-448. In: J. Mascaró Pasarius (ed.). Historia de Mallorca, vol. I.

Colls, D., C. Descamps, and C. Grasselly. 1985. Des amandes sur une épave antique. Options Méditerr. CIHEAM/IAMZ 85/I:105-106.

Felipe, A.J. 1984. Etat actuel de l'arboretum des espèces sauvages d'amandier à Saragosse. Options Méditerr. CIHEAM/IAMZ84/II:203-204.

Felipe, A.J. and R. Socias i Company. 1985a. Estado actual de los estudios de material vegetal en España. Almendro. Inf. Técn. Econ. Agrar. Extra 4:223-250.

Felipe, A.J. and R. Socias i Company. 1985b. L'amélioration génétique de l'amandier à

(continued on inside buck cover) 
Saragosse. Options Méditerr. CIHEAM/IAMZ 85/I:9-14.

Felipe, A.J. and R. Sociasi Company. 1987. 'Aylés', 'Guara', and 'Moncayo' almonds. HortScience 22:961-962.

Godini, A. 1979. Ipotesi sulla comparsa dell'autocompatibilità nel mandorlo. Riv. Sci. Tecn. Agrar. 19(2/3):3-10.

Grasselly, C. 1976. Les espèces sauvages d'amandier. Options Méditerr. 32:28-43.

Grasselly, C. and P. Crossa-Raynaud. 1980. L'amandier. G.P. Maisonneuve et Larose, Paris.

Graves, R. 1955. The Greek myths. George Braziller, New York.

Herrero, M. and A.J. Felipe. 1975. Pollinisation de l'amandier. Incompatibilité pollen-style.' $2^{\circ}$ Colloq. GREMPA, Montpellier-Nimes, Sept. 1975.

Kester, D.E. and R. Asay. 1975. Almonds, p. $387-$
419. In: J. Janick and J.N. Moore (ed.). Advances in fruit breeding. Purdue Univ. Press, West Lafayette, Ind.

Kester, D.E., T.M. Gradziel, and C. Grasselly. 1990. Almonds (Prunus), p. 699-758. In: J.N. Moore and J. R. Ballington (ed.). Genetic resources of temperate fruit and nut crops. Acta Hort. 290(2).

Kovalyov, N.V. and K.F. Kostina. 1935. A contribution to the study of the genus Prunus Focke. Questions of taxonomy and plant breeding (In Russian, English summary). Tr. Prikl. Bot. Genet. Selek., Ser. 8,4:1-76.

Popov, M.G., K.F. Kostina, and A.I. Poyarkova. 1929. Wild trees and shrubs in Central Asia (In Russian, English summary). Tr. Prikl. Bot. Genet. Selek. 22:241-483.

Socias i Company, R. 1977. La autoincompatibilidad en el almendro. Inf. Técn. Econ. Agrar. 26:4147.

Socias i Company, R. 1990. Breeding self-compatible almonds. Plant Breeding Rev. 8:313-338.
Socias i Company, R. and A.J. Felipe. 1988. Presence and self-compatibility of Prunus webbii in Spain. Intl. Symp. Hort. Germplasm, Cultivated \& Wild, Beijing, China. Sept. 1988.

Spiegel-Roy, P. 1986. Domestication of fruit trees, p. 210-211. In: C. Barigozzi (ed.). The origin and domestication of cultivated plants. Elsevier, Amsterdam.

Watkins, R. 1979. Cherry, plum, peach, apricot and almond: Prunus spp., p. 242-247. In: N.W. Simmonds (ed.). Evolution of crop plants. Longman, London.

R. Socias i Company and A.J. Felipe Unidad de Fruticultura Servicio de Investigacion Agraria Diputacion General de Agragon (INIA)

Apartado 727 50080 Zaragoza, Spain 